\title{
Organic carbon and mineral nutrient limitation of oxygen consumption, bacterial growth and efficiency in the Norwegian Sea
}

\author{
L. Antonio Cuevas · Jorun K. Egge • \\ T. Frede Thingstad $\cdot$ Birte Töpper
}

Received: 3 May 2010/Revised: 1 November 2010/Accepted: 16 December 2010/Published online: 12 January 2011

(C) The Author(s) 2011. This article is published with open access at Springerlink.com

\begin{abstract}
To evaluate the role of bacteria in the transformation of organic matter in subarctic waters, we investigated the effect of mineral nutrients (ammonia and phosphate) and organic carbon (glucose) enrichment on heterotrophic bacterial processes and community structure. Eight experiments were done in the Norwegian Sea during May and June 2008. The growth-limiting factor (carbon or mineral nutrient) for heterotrophic bacteria was inferred from the combination of nutrient additions that stimulated highest bacterial oxygen consumption, biomass, production, growth rate and bacterial efficiency. We conclude that heterotrophic bacteria were limited by organic carbon and co-limited by mineral nutrients during the prevailing early nano-phytoplankton $(1-10 \mu \mathrm{m})$ bloom conditions. High nucleic acid (HNA) bacteria became dominant $(>80 \%)$ only when labile carbon and mineral nutrient sources were available. Changes in bacterial community structure were investigated using denaturing gradient gel electrophoresis (DGGE) of polymerase chain reaction (PCR)-amplified $16 \mathrm{~S}$ ribosomal RNA genes. The bacterial community structure changed during incubation time, but neither carbon nor mineral nutrient amendment induced changes at the end of the experiments. The lack of labile organic carbon and the availability of mineral nutrients are key factors controlling bacterial activity and the role of the microbial food web in carbon sequestration.
\end{abstract}

Keywords Bacterial growth - Mineral nutrient limitation - Carbon limitation - Oxygen consumption · Norwegian Sea

L. A. Cuevas $(\bowtie) \cdot$ J. K. Egge · T. F. Thingstad · B. Töpper

Department of Biology, University of Bergen,

P.O. Box 7803, 5020 Bergen, Norway

e-mail: Luis.Cuevas@bio.uib.no

\section{Introduction}

Arctic and subarctic pelagic ecosystems are often used as examples of short and linear classical food webs, but several studies have also emphasised the importance of the microbial food web in carbon and mineral nutrient transformations in subarctic areas. Most of these studies have focused on the Barents Sea (Allen et al. 2002; Sturluson et al. 2008; Tammert et al. 2008), the western Arctic Ocean (Kirchman et al. 2005, 2009; Elifantz et al. 2007; Malmstrom et al. 2007), or the central Arctic Ocean (Rich et al. 1997; Sherr and Sherr 2003). Very few studies, however, have been conducted in the Norwegian and Greenland Seas (Børsheim and Myklestad 1997; Børsheim 2000), areas of deep water formation (Rahmstorf 2002), both of which contribute significantly to biological sequestration of atmospheric carbon dioxide $\left(0.7 \pm 0.1 \mathrm{Pg} \mathrm{C}\right.$ year $^{-1}$, Gruber et al. 2002).

Relatively high bacterial production $\left(\sim 0.26 \mu \mathrm{M} \mathrm{d}^{-1}\right)$ has been reported in the euphotic zone of the Norwegian Sea, when compared with warmer North Atlantic waters at the end of the productive season (Børsheim 2000). In Arctic and subarctic areas, the increase in bacterial abundance after phytoplankton blooms suggests that substrate control dominates over temperature control (Sherr and Sherr 2003). The phytoplankter Phaeocystis pouchetii (Haptophyta: Prymnesiophyceae), for example, is rich in carbohydrate mucilage and dominant in the Greenland Sea during phytoplankton blooms (Smith et al. 1991). P. pouchetii can thereby enrich the labile dissolved organic carbon (DOC) pool in C-rich material, although bacterial degradation of this DOC presumably requires inorganic $\mathrm{N}$ and $\mathrm{P}$ (Thingstad and Billen 1994). Furthermore, depletion of mineral nutrients can slow down the heterotrophic processes; thus, DOC with low N or P content may be partially resilient to degradation by heterotrophic bacteria (Broström 1998). In addition to nutrient 
limitation, complex and ambiguous interaction between temperature and bacterial production has also been suggested (Kirchman et al. 2005). Indeed, heterotrophic bacteria in cold waters seem to need higher concentrations of organic substrates to approach growth rates observed in warm waters (Pomeroy and Wiebe 2001).

Based on results from a mesocosm experiment conducted in Arctic coastal waters (Thingstad et al. 2008), it has been suggested that the mechanisms controlling the fate of organic carbon are fundamentally different, depending on whether the system is in an organic carbonor mineral nutrient-limited state. An idealised microbial food web (e.g. Fig. 1 in Thingstad et al. 2008) can be used to illustrate the expected sequence of events: From the prebloom situation with free mineral nutrients and an expected carbon limitation of bacterial growth rate, the transition into a bloom state dominated by phytoplankton will produce a combination of strong competition for mineral nutrients with little recycling from phagotrophs. This will favour a state where bacterial growth is limited by mineral nutrients, and DOC can accumulate in the system. In the post-bloom situation with fewer osmotrophs (mainly phytoplankton) and more phagotrophs (grazers), the combination of reduced competition with increased recycling would be expected to allow for more degradation of labile organic matter, potentially shifting the system back to a state where bacterial growth is limited by organic carbon. Following these ideas, it becomes highly desirable to understand the state of bacterial limitation in general, and in this particular case, its role in the seasonal fluctuations of DOC observed in the Norwegian Sea (Børsheim and Myklestad 1997).

Nutrient-manipulated experiments have shown that distinct groups respond differently to nutrients additions (Teira et al. 2010), and long-term incubation can measure mainly the activity of the opportunistic bacteria instead of

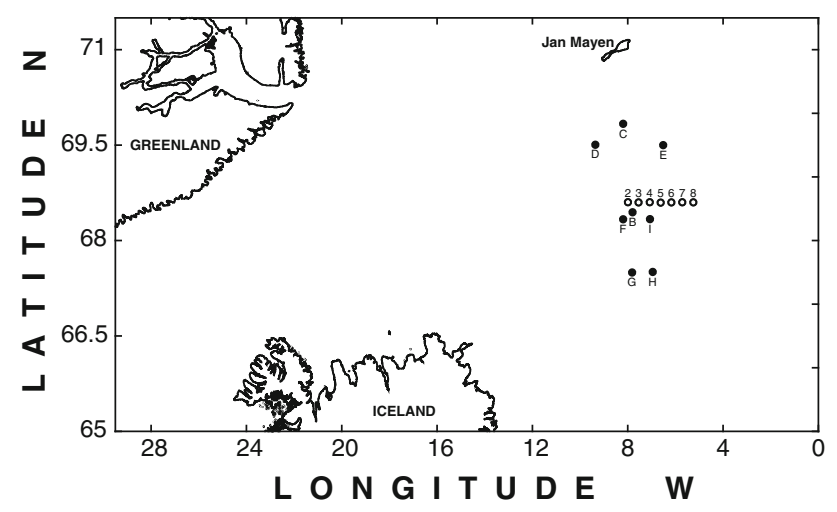

Fig. 1 Sampling stations during NESSAR cruise (May and June, 2008) in the Greenland and Norwegian Seas. Dark circles represent experimental stations and open circles represent west-east transect stations the original community (Massana et al. 2001). In an arctic mesocosm experiment, the bacterial community composition can be affected by the additions of glucose and silicate with a large effect from glucose (Töpper et al. 2010).

The aim of this study was thus to give a first set of data on how marine heterotrophic bacteria are limited in subarctic systems (e.g. the Norwegian Sea). The importance of carbon sources (glucose) and inorganic nutrients (ammonia and phosphate) for bacterial respiration and production was tested, and the type of limitation correlated with changes in bacterial community. These results might have a particular importance when considering the role of bacteria in biogeochemical processes and the potential sequestration of $\mathrm{CO}_{2}$ in this subarctic area.

\section{Methods}

Water-column sampling and oxygen bioassay set-up

A research cruise was carried out between 22 May and 6 June 2008 in the Norwegian and Greenland Sea onboard the R/V Joan Hjort, at both sides and within the subarctic front south of Jan Mayen island (Fig. 1). Across the subarctic front, six stations were sampled at $68^{\circ} 30^{\prime} \mathrm{N}$ at almost every 30' from west (Arctic) to east (Atlantic waters). CTD profiles and water-column samples for chlorophyll-a (chla), bacterial abundance (BA) and inorganic nutrients (nitrate, phosphate and silicate) were taken using a General Oceanic Rosette equipped with $5 \mathrm{~L}$ Niskin bottles from fixed depths $(5,10,20,30,40,50,75$ and $100 \mathrm{~m})$. Bacterial abundance and total organic carbon (TOC) were sampled only above $50 \mathrm{~m}$ depth.

In order to identify the factors controlling bacterial growth, eight separate experiments were performed. For each experiment, approximately $20 \mathrm{~L}$ of sea water was collected from $10 \mathrm{~m}$ depth (once from $20 \mathrm{~m}$ ) following the fluorescent maximum from CTD profiles (data not shown). Samples for size-fractionated chla measurement and DGGE analysis were taken first (see below), and the remaining approx. $5 \mathrm{~L}$ of sea water was filtered using a $1.0 \mu \mathrm{m}$ polycarbonate filter over a GF/C filter, both of $47 \mathrm{~mm}$ diameter.

Bioassays were performed in BOD bottles of $125 \mathrm{ml}$ in darkness. Temperature was kept constant using running surface sea water $\left( \pm 2^{\circ} \mathrm{C}\right)$. Prior to incubation, the bottles were supplied with either ammonia + phosphate $(\mathrm{N}+\mathrm{P})$, or glucose $(\mathrm{C}$, as DOC source), or ammonia + phosphate + glucose $(\mathrm{N}+\mathrm{P}+\mathrm{C})$, or controls without additions. Ammonia additions were preferred instead of nitrate to allow bloom conditions for small cells (e.g. bacteria, pico- and nano-phytoplankton) (Lipschultz 1995). $\mathrm{N}+\mathrm{P}+\mathrm{C}$ treatments represent a non-mineral nutrient limitation system that could allow higher production and 
growth rates for heterotrophic bacteria. Final concentrations of 10,100 and 1,000 $\mu \mathrm{M}$ for phosphate, ammonia and glucose, respectively, were added to each experimental BOD bottle. All treatments were performed in triplicate, resulting in a total of 12 bottles per experiment. At the beginning of each experiment, samples for bacterial abundance and bacterial production (BP) were taken. Oxygen concentration was measured daily using an OxyMini ${ }^{\circledR}$ optode system (World Precision Instruments) at constant temperature $\left( \pm 1^{\circ} \mathrm{C}\right)$. Each BOD bottle had a membrane sensor that allowed measurement of oxygen without opening the bottles. Bottles with headspace or bubbles were not used for calculations. Consumption of oxygen was used as a treatment response, and every experiment was stopped when minimum oxygen concentrations were detected (after 4-6 days). Finally, at the end of each experiment, samples for bacterial abundance, bacterial production and DGGE were taken.

\section{Total organic carbon measurements}

Samples for TOC were collected directly from the rosette (transect) in $7.5 \mathrm{ml}$ Supelco vials with Teflon-lined caps, acidified with phosphoric acid and stored at $4^{\circ} \mathrm{C}$. TOC was measured no later than 2 months after sampling using a high-temperature catalytic combustion technique (Suzuki et al. 1992; Sharp et al. 1993) with a Dohrmann DC 190 analyser. After acidification to $\mathrm{pH} 2$, samples were sparged with pure oxygen to remove inorganic carbon. From each sample, five times $200 \mu \mathrm{l}$ was injected by an autosampler. To minimise carryover effects, a Milli-Q water blank was placed between every sample. On average, the standard error was lower than $0.5 \%(0.4 \mu \mathrm{M})$ for all samples.

Phytoplankton biomass, bacteria biomass

and bacterial production

Water samples for chla measurements (as phytoplankton biomass proxy) were filtered in triplicate onto $47-\mathrm{mm}$ polycarbonate filters (Microfiltrations Systems) using three size fractions $0.2-1 \mu \mathrm{m}, 1-10 \mu \mathrm{m}$ and $>10 \mu \mathrm{m}$. Sizefractioned chla was measured only at the same depth of the experiments (bioassays). Chla was extracted in $90 \%$ acetone at $4^{\circ} \mathrm{C}$ for $10-12 \mathrm{~h}$ and then measured by autofluorescence (Parsons et al. 1984) using a Turner Designs 10-AU Fluorometer calibrated with pure chla (Sigma Chemicals Inc).

Samples for bacterial counts were fixed with glutaraldehyde $(0.5 \%(\mathrm{v} / \mathrm{v})$ final concentration), stained with SYBR Green I (Molecular Probes Inc., Eugene, OR) and counted using a flow cytometer (FACSCalibur, BectonDickinson, Franklin Lakes, NJ) equipped with an aircooled laser providing $15 \mathrm{~mW}$ at $488 \mathrm{~nm}$ and with a standard filter set-up (Marie et al. 1999). Low nucleic acid (LNA) bacteria and high nucleic acid (HNA) bacteria were counted using green fluorescence signal on the cytograms. The separation in both groups will be used as proxy for fast-growing versus low-growing bacteria, respectively. Bacterial abundance was converted to bacterial biomass (BB) under the assumption that bacterial carbon content is 20 fg C cell ${ }^{-1}$ (Lee and Fuhrman 1987). For bacterial production experiments, triplicate samples of $1.5 \mathrm{ml}$ and a formalin-killed control were incubated with tritium-labelled leucine (Amersham, $1.15 \times 10^{10} \mathrm{~Bq} \mathrm{mmol}^{-1}$ ) at a final concentration of $50 \mathrm{nM}$ (Simon and Azam 1989) in the dark at in situ temperature for $1 \mathrm{~h}$. After incubation, samples were extracted with $100 \%$ trichloroacetic acid (TCA) and rinsed with cold 5\% TCA and centrifuged at $14,000 \times g$ twice for $10 \mathrm{~min}$ before the removal of supernatant (Smith and Azam 1992). Counting cocktail (Ecoscint A, National Diagnostics) was added, and the uptake of radioactive leucine was measured on a Tri-Carb 2900TR, Perkin Elmer scintillation counter. Cell carbon produced per mol of leucine incorporated was based on the theoretical conversion factor proposed by Simon and Azam (1989) using the average value of $1.55 \mathrm{kgC} \mathrm{mol}^{-1}$ assuming no isotope dilution. Leucine incorporation was converted into biomass production using the carbon fraction of proteins of 0.86 (Simon and Azam 1989).

Oxygen utilisation, bacterial growth rates and growth efficiency

Oxygen consumption was calculated as the average (from 3 BOD bottles) of the differences between oxygen values every $24 \mathrm{~h}$ during 4-6 days of incubation $\left(\mathrm{O}_{2}\left(\mathrm{t}_{24}\right)-\mathrm{O}_{2}\left(\mathrm{t}_{0}\right)\right)$.

Bacterial growth rate (BGR) was calculated for each treatment (control; N $+\mathrm{P} ; \mathrm{C} ; \mathrm{N}+\mathrm{P}+\mathrm{C}$ ) as the quotient of bacterial production (from the previous leucine bacterial production experiments) and bacterial biomass (BGR $=$ $\mathrm{BP} / \mathrm{BB})$. Bacterial growth efficiency was calculated as the quotient of net production and gross production $(\mathrm{BGE}=$ $\mathrm{BP} /[\mathrm{BP}+\mathrm{BR}])$, where $\mathrm{BR}$ is bacterial respiration estimated from the above-mentioned oxygen consumption experiments. Error was calculated from propagation of the measured error for bacterial respiration and production.

\section{Denaturing gradient gel electrophoresis (DGGE)}

To obtain samples for DGGE analysis, $500 \mathrm{ml}$ of sea water was filtered at time zero $\left(T_{0}\right)$, and $105-350 \mathrm{ml}$ was filtered at the end of the experiment $\left(T_{\mathrm{f}}\right)$ through sterile $0.2-\mu \mathrm{m}$ polycarbonate filters $(47 \mathrm{~mm})$. For all $T_{\mathrm{f}}$ samples, the volume filtered depended on the sea water available of the limited volume in each BOD bottle (3 replicates). The filters were stored at $-80^{\circ} \mathrm{C}$ until further processing. DNA 
isolation was performed using a modified protocol of Bailey et al. (1995). Oligonucleotide primers EUB-f (Giovannoni et al. 1990) with GC-clamp (Øvreås et al. 1997) and 518r (Lane et al. 1985) were used to amplify partial bacterial 16S rDNA using the following temperature program: initial denaturation for $9 \mathrm{~min}$ at $94^{\circ} \mathrm{C} ; 35$ cycles of $30 \mathrm{~s}$ at $94^{\circ} \mathrm{C}, 1.5 \mathrm{~min}$ at $54^{\circ} \mathrm{C}$ and $30 \mathrm{~s}$ at $72^{\circ} \mathrm{C}$; a final elongation for $7 \mathrm{~min}$ at $72 \mathrm{C}$. Approximately equal amounts of PCR products were loaded onto $7 \%$ acrylamide gels with a denaturing gradient from $30-60 \%$, where $100 \%$ denaturing is defined as $7 \mathrm{M}$ urea and $40 \%$ formamide (Muyzer et al. 1993). Samples were run at $100 \mathrm{~V}$ for $16 \mathrm{~h}$ at $60^{\circ} \mathrm{C}$ in a DCode system (BioRad, Herts, UK). SYBR Gold-stained gels were visualised and digitalised using the Fujifilm Imaging System (LAS-1000). Gel $2 \mathrm{~K}$ software (Svein Norland, Department of Biology, University of Bergen) was used to analyse the DGGE images based on the presence or absence of DGGE bands. Band patterns were transformed into binary data and compared using the program Primer 6 (Primer-E, Plymouth, UK). The JaccardIndex was used to test for similarities between DGGE banding patterns. The resulting resemblance matrix served as basis for non-metric multidimensional scaling (NMDS).

\section{Results}

Hydrographic conditions, chla, mineral nutrients, TOC and BA

A weak subarctic front was distinguished from the CTD casts at $68^{\circ} 30^{\prime}$ latitude $\mathrm{N}$ with cold and fresher waters $\left(<4.5^{\circ} \mathrm{C}\right.$ and $\left.<34.90\right)$ of Arctic influence and warm and salty waters $\left(>4.5^{\circ} \mathrm{C}\right.$ and $\left.>34.98\right)$ of Atlantic influence from the Norwegian Sea (K. Drinkwater, pers. comm.). A weak thermocline was always found between $25-45 \mathrm{~m}$ depth in all sampling stations (data not showed). Total chla ranged from $0.02-2.5 \mu \mathrm{g} \mathrm{L}^{-1}$ in the upper $100 \mathrm{~m}$ and from $0.50-2.5 \mu \mathrm{g} \mathrm{L}^{-1}$ above $20 \mathrm{~m}$ depth (Table 1) with a subsurface chla maximum between 10 and $20 \mathrm{~m}$ depth. In all the experiments, the nano-planktonic fraction $(1-10 \mu \mathrm{m})$ represented between $47-87 \%$ of the total chla. Microplanktonic $(>10 \mu \mathrm{m})$ and pico-planktonic autotrophic cells $(0.2-1 \mu \mathrm{m})$ accounted for $4-45 \%$ and $5-11 \%$, respectively (Table 2).

Lowest concentrations of inorganic nutrients were measured in the surface layer above the halocline. Nutrient concentrations increased below $20 \mathrm{~m}$ and were constant along the transect (Table 1). Nitrate varied from 2.5-12.2 $\mu \mathrm{M}$, phosphate from $0.33-0.85 \mu \mathrm{M}$ and silicate varied from $2.8-5.3 \mu \mathrm{M}$ until $100 \mathrm{~m}$ depth. Similarly, at the depth of the experiments, nitrate, phosphate and silicate values were in the same range than along the transect
(Table 2). Only station $\mathrm{G}$ had lower values with averages of $0.39 \mu \mathrm{M}$ of nitrate, $0.18 \mu \mathrm{M}$ of phosphate and $2.02 \mu \mathrm{M}$ of silicate (Table 2).

In surface waters $(0-50 \mathrm{~m}$ depth), TOC varied from 45-94 $\mu \mathrm{M}$, with values higher than $80 \mu \mathrm{M}$ only at the Atlantic side of the front (above $10 \mathrm{~m}$ depth), and a homogenous distribution $(\sim 60 \mu \mathrm{M})$ for most of the stations in the Atlantic, within the front and in the Arctic waters (Table 1). At the depths of the experiments, TOC was not different between Arctic and Atlantic waters (Table 2). Only for experiment $\mathrm{F}$ were TOC values higher than $80 \mu \mathrm{M}$, while experiments $\mathrm{C}, \mathrm{D}$ and $\mathrm{E}$ yielded remarkably low values of $54.2,53.9$ and $54.2 \mu \mathrm{M}$, respectively (Table 2). BA ranged from $0.58-1.54 \times 10^{6}$ cells $\mathrm{ml}^{-1}$ with maximum average values $\left(>1.20 \times 10^{6}\right.$ cells $\mathrm{ml}^{-1}$ ) in Atlantic waters above $20 \mathrm{~m}$ depth (Table 1). The Arctic side of the front was represented by BA values

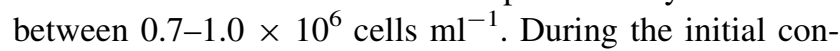
dition of the experiments, only experiments $\mathrm{G}$ and $\mathrm{H}$ presented values higher than $1 \times 10^{6}$ cells ml $^{-1}$ (Table 2).

Oxygen consumption, bacterial biomass and production during addition experiments

Oxygen consumption rates in the control treatments ranged from 4.4 to $30.4 \mu \mathrm{mol} \mathrm{O}_{2} \mathrm{~L}^{-1}$ day $^{-1}$ (Table 2). A decrease in oxygen for the $<1 \mu \mathrm{m}$ microbial community was observed during the first $24 \mathrm{~h}$ of incubation, with a high variability between experiments but no significant differences between treatments (Fig. 2). Oxygen consumption during the first $24 \mathrm{~h}$ varied from a minimum of 17.7 to a maximum rate of $101.6 \mu \mathrm{mol} \mathrm{O} \mathrm{O}_{2} \mathrm{~L}^{-1}$ day $^{-1}$ for experiments $\mathrm{H}$ and $\mathrm{I}$, respectively. A period with minor changes was observed between 24 and 72 h (Fig. 2). Oxygen consumption increased after $72 \mathrm{~h}$ in all bottles amended with glucose addition (C), and especially in $\mathrm{N}+\mathrm{P}+\mathrm{C}$ additions. Oxygen consumption in mineral nutrient amended bottles $(\mathrm{N}+\mathrm{P})$ was not significantly different from controls (Fig. 2). No clear differences were found between water masses (e.g. Arctic, Atlantic) for $\mathrm{C}$ and $\mathrm{N}+\mathrm{P}+\mathrm{C}$ additions. Oxygen consumption for control and $\mathrm{N}+\mathrm{P}$ treatments ranged from 2.9 to $30.4 \mu \mathrm{M} \mathrm{O}_{2} \mathrm{~L}^{-1}$ day $^{-1}$, in the $\mathrm{C}$ treatments it ranged from 6.0 to $30.0 \mu \mathrm{M} \mathrm{O}_{2} \mathrm{~L}^{-1}$ $\mathrm{day}^{-1}$. The highest rates were detected for the $\mathrm{N}+\mathrm{P}+\mathrm{C}$ treatment ranging from 25.0 to $76.1 \mu \mathrm{M} \mathrm{O}_{2} \mathrm{~L}^{-1}$ day $^{-1}$ with the exception of a low value in experiment $\mathrm{C}\left(10.7 \mu \mathrm{M} \mathrm{O}_{2}\right.$ $\mathrm{L}^{-1}$ day $^{-1}$ ) (Fig. 2).

In control and $\mathrm{N}+\mathrm{P}$ treatments, $\mathrm{BB}(t$ test $=0.297$, $P>0.05)$ and BP ( $t$ test $=0.270, P>0.05)$ were not statistically different, showing average values of $28.9 \pm$ $10.2 \mu \mathrm{g} \mathrm{C} \mathrm{L}^{-1}$ and $1.1 \pm 0.5 \mu \mathrm{g} \mathrm{C} \mathrm{L}^{-1} \mathrm{~h}^{-1}$, respectively (Fig. 3a, b). In $\mathrm{C}$ amended bottles, BB varied from 32.4 to $72.3 \mu \mathrm{g} \mathrm{C} \mathrm{L}^{-1}$ after 4-6 days of incubation (Fig. 3a), and 
Table 1 Average and standard deviation of chlorophyll-a (chla), mineral nutrients (nitrate, phosphate and silicate), total organic carbon (TOC) and bacterial abundance (BA) at $68^{\circ} 30^{\prime} \mathrm{N}$ transect

\begin{tabular}{|c|c|c|c|c|c|c|c|c|}
\hline Station & Water (mass) & Depth & Chla $\left(\mu \mathrm{g} \mathrm{L}^{-1}\right)$ & Nitrate $(\mu \mathrm{M})$ & Phosphate $(\mu \mathrm{M})$ & Silicate $(\mu \mathrm{M})$ & TOC $(\mu \mathrm{M})$ & $\begin{array}{l}\text { BA } \\
\left(\times 10^{6} \text { cells } \mathrm{ml}^{-1}\right)\end{array}$ \\
\hline \multirow[t]{2}{*}{2} & Arctic & Surface & $1.13 \pm 0.39$ & $4.65 \pm 1.55$ & $0.49 \pm 0.07$ & $4.37 \pm 0.20$ & $60.0 \pm 2.43$ & $0.77 \pm 0.11$ \\
\hline & & Deep & $0.18 \pm 0.12$ & $9.83 \pm 1.44$ & $0.71 \pm 0.08$ & $4.79 \pm 0.12$ & $54.5 \pm 2.08$ & $0.75 \pm 0.25$ \\
\hline \multirow[t]{2}{*}{3} & Arctic & Surface & $1.37 \pm 0.78$ & $4.75 \pm 2.56$ & $0.49 \pm 0.13$ & $4.34 \pm 0.27$ & $66.7 \pm 1.45$ & $0.91 \pm 0.15$ \\
\hline & & Deep & $0.15 \pm 0.08$ & $10.39 \pm 0.67$ & $0.77 \pm 0.03$ & $4.84 \pm 0.08$ & $53.4 \pm 1.01$ & $0.68 \pm 0.14$ \\
\hline \multirow[t]{2}{*}{4} & Front & Surface & $1.30 \pm 0.65$ & $5.70 \pm 2.72$ & $0.54 \pm 0.14$ & $4.45 \pm 0.17$ & $64.1 \pm 2.01$ & $1.29 \pm 0.23$ \\
\hline & & Deep & $0.15 \pm 0.14$ & $10.52 \pm 1.29$ & $0.78 \pm 0.06$ & $4.90 \pm 0.24$ & $50.2 \pm 2.59$ & $1.01 \pm 0.44$ \\
\hline \multirow[t]{2}{*}{5} & Atlantic & Surface & $2.04 \pm 0.33$ & $4.06 \pm 0.61$ & $0.45 \pm 0.04$ & $4.26 \pm 0.18$ & $61.7 \pm 2.00$ & $1.33 \pm 0.18$ \\
\hline & & Deep & $0.15 \pm 0.15$ & $10.57 \pm 1.47$ & $0.77 \pm 0.06$ & $4.96 \pm 0.19$ & $45.1 \pm 0.01$ & $0.88 \pm 0.34$ \\
\hline \multirow[t]{2}{*}{6} & Atlantic & Surface & $1.61 \pm 0.84$ & $5.08 \pm 2.47$ & $0.50 \pm 0.13$ & $4.53 \pm 0.15$ & $\mathrm{NE}$ & $\mathrm{NE}$ \\
\hline & & Deep & $0.07 \pm 0.05$ & $11.38 \pm 0.82$ & $0.81 \pm 0.03$ & $5.08 \pm 0.17$ & $\mathrm{NE}$ & $\mathrm{NE}$ \\
\hline \multirow[t]{2}{*}{7} & Atlantic & Surface & $1.70 \pm 0.12$ & $3.36 \pm 1.18$ & $0.39 \pm 0.07$ & $4.01 \pm 0.09$ & $89.0 \pm 3.94$ & $0.95 \pm 0.08$ \\
\hline & & Deep & $0.26 \pm 0.21$ & $10.28 \pm 1.29$ & $0.76 \pm 0.04$ & $4.64 \pm 0.10$ & $51.5 \pm 1.93$ & $0.83 \pm 0.05$ \\
\hline \multirow[t]{2}{*}{8} & Atlantic & Surface & $1.23 \pm 0.15$ & $3.19 \pm 0.40$ & $0.35 \pm 0.03$ & $3.02 \pm 0.16$ & $62.3 \pm 2.62$ & $1.17 \pm 0.22$ \\
\hline & & Deep & $0.42 \pm 0.28$ & $9.03 \pm 2.40$ & $0.72 \pm 0.09$ & $4.31 \pm 0.31$ & $61.8 \pm 4.50$ & $0.70(\mathrm{NE})$ \\
\hline
\end{tabular}

Surface water: $0-20 \mathrm{~m}$ and deep water: $30-100 \mathrm{~m}$ depth

TOC was measured above $50 \mathrm{~m}$ depth. $N E$ not estimated

Table 2 Initial condition for each dissolved oxygen consumption experiments in the Norwegian Sea

\begin{tabular}{|c|c|c|c|c|c|c|c|c|c|c|c|}
\hline Experiment & $\begin{array}{l}\text { Water } \\
\text { (mass) }\end{array}$ & $\begin{array}{l}\text { Inc. time } \\
\text { (days) }\end{array}$ & $\begin{array}{l}\text { Inc. } \\
\text { Temp }{ }^{\circ} \mathrm{C}\end{array}$ & $\begin{array}{l}\text { Chl- } a \\
\left(\mu \mathrm{g} \mathrm{L}^{-1}\right)\end{array}$ & $\begin{array}{l}\text { TOC } \\
(\mu \mathrm{M})\end{array}$ & $\begin{array}{l}\text { Nitrate } \\
(\mu \mathrm{M})\end{array}$ & $\begin{array}{l}\text { Phosphate } \\
(\mu \mathrm{M})\end{array}$ & $\begin{array}{l}\text { Silicate } \\
(\mu \mathrm{M})\end{array}$ & $\begin{array}{l}\text { BA } \\
\left(\times 10^{6} \text { cells } \mathrm{mL}^{-1}\right)\end{array}$ & $\begin{array}{l}\mathrm{BP} \\
\left(\mu \mathrm{gC} \mathrm{L} \mathrm{L}^{-1} \mathrm{~h}^{-1}\right)\end{array}$ & $\begin{array}{l}\mathrm{BR} \\
\left(\mu \mathrm{M} \mathrm{O}_{2} \mathrm{~L}^{-1} \text { day }^{-1}\right)\end{array}$ \\
\hline B & Mixed & 6 & 4.0 & $\begin{array}{l}0.220 .2-1 \mu \mathrm{m} \\
1.521-10 \mu \mathrm{m} \\
0.30>10 \mu \mathrm{m}\end{array}$ & 60.9 & 4.92 & 0.50 & 4.47 & 0.69 & 0.058 & 4.4 \\
\hline $\mathrm{C}$ & Mixed & 6 & 4.0 & $\begin{array}{l}0.140 .2-1 \mu \mathrm{m} \\
1.461-10 \mu \mathrm{m} \\
0.39>10 \mu \mathrm{m}\end{array}$ & 54.2 & - & - & - & 0.54 & 0.047 & 4.7 \\
\hline D & Arctic & 6 & 5.0 & $\begin{array}{l}0.090 .2-1 \mu \mathrm{m} \\
0.821-10 \mu \mathrm{m} \\
0.73>10 \mu \mathrm{m}\end{array}$ & 53.9 & 5.34 & 0.52 & 3.66 & 0.63 & 0.082 & 7.1 \\
\hline $\mathrm{E}$ & Atlantic & 5 & 5.0 & $\begin{array}{l}0.130 .2-1 \mu \mathrm{m} \\
0.991-10 \mu \mathrm{m} \\
0.21>10 \mu \mathrm{m}\end{array}$ & 54.2 & - & - & - & 0.65 & 0.039 & 7.2 \\
\hline $\mathrm{F}$ & Arctic & 6 & 6.0 & $\begin{array}{l}0.140 .2-1 \mu \mathrm{m} \\
1.181-10 \mu \mathrm{m} \\
0.64>10 \mu \mathrm{m}\end{array}$ & 83.8 & 5.08 & 0.44 & 4.34 & 0.95 & 0.103 & 8.5 \\
\hline G & Arctic & 6 & 6.0 & 4.65 total chla & 72.5 & 0.39 & 0.18 & 2.02 & 1.81 & 0.074 & 13.2 \\
\hline $\mathrm{H}$ & Front & 4 & 6.5 & $\begin{array}{l}0.080 .2-1 \mu \mathrm{m} \\
0.851-10 \mu \mathrm{m} \\
0.37>10 \mu \mathrm{m}\end{array}$ & 72.9 & - & - & - & 2.16 & 0.163 & 30.4 \\
\hline I & Atlantic & 4 & 6.0 & $\begin{array}{l}0.16 \\
0.2-1.0 \mu \mathrm{m} \\
1.031 .0-10 \mu \mathrm{m} \\
1.00>10 \mu \mathrm{m}\end{array}$ & 71.0 & 2.51 & 0.36 & 4.20 & 0.97 & 0.166 & 12.9 \\
\hline
\end{tabular}

All experiments were done at $10 \mathrm{~m}$ depth, except experiment $\mathrm{C}$ (at $20 \mathrm{~m}$ ) 
Fig. 2 Oxygen concentration over time in amended bottles and controls. Error bands represent standard deviation (SD) between replicates
Fig. 3 Logarithmic bacterial biomass (a), logarithmic bacterial production (b), bacterial growth rate (c) and bacterial growth efficiency (d) in all experiments (means $\pm \mathrm{SD}$ ). $\mathrm{N}+\mathrm{P}$ : mineral nutrient additions; $\mathrm{C}$ : carbon additions and $\mathrm{N}+\mathrm{P}+\mathrm{C}$ : mineral nutrient plus carbon additions
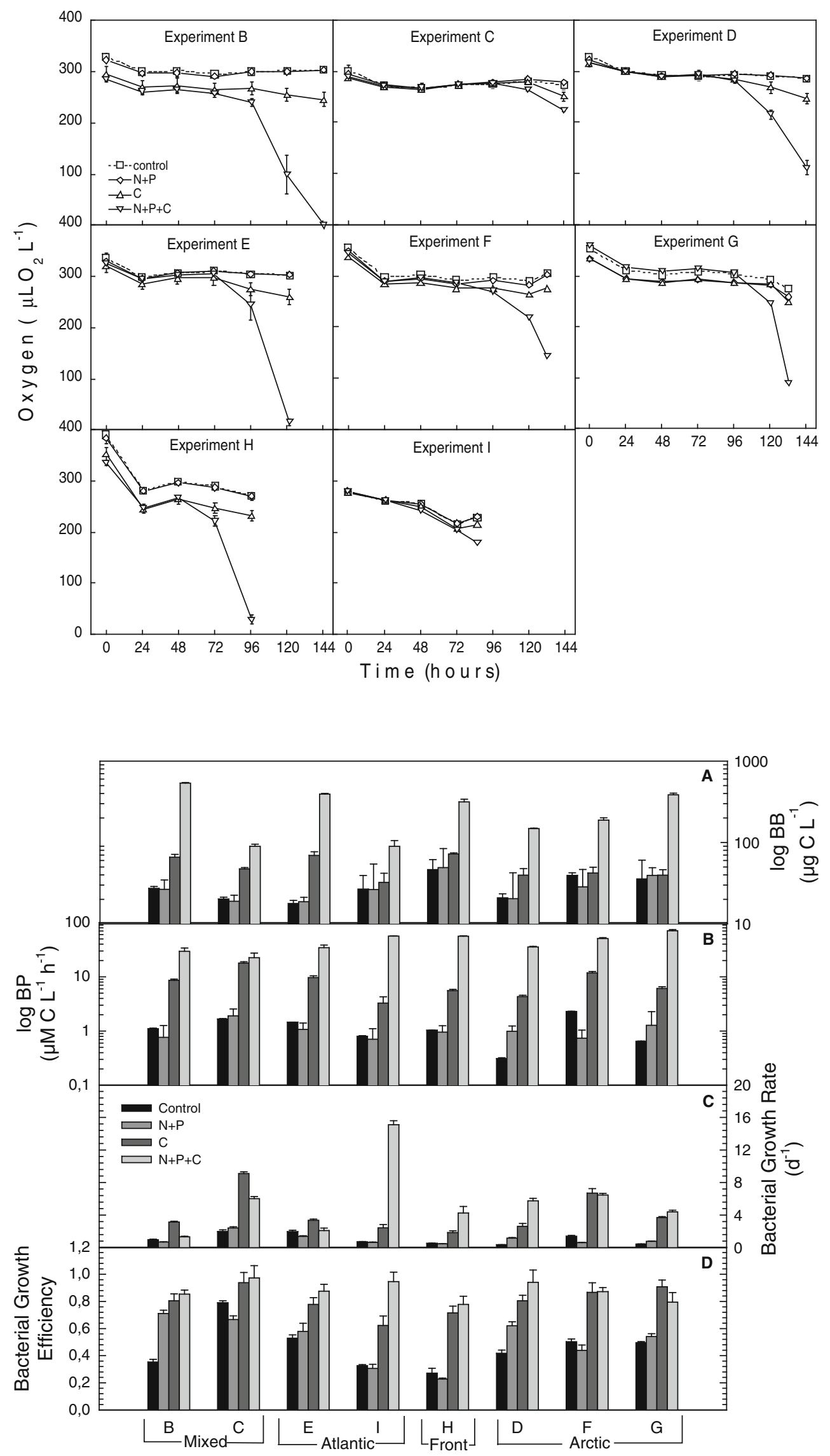
BP varied from 3.3 to $18.0 \mu \mathrm{g} \mathrm{C} \mathrm{L}^{-1} \mathrm{~h}^{-1}$ after the same incubation period (Fig. 3b). The biggest increase in biomass and production was observed for the $\mathrm{N}+\mathrm{P}+\mathrm{C}$ additions with values that varied from 89.6 to $535.3 \mu \mathrm{g} \mathrm{C}$ $\mathrm{L}^{-1}$ and from 22.5 to $70.5 \mu \mathrm{g} \mathrm{C} \mathrm{L}^{-1} \mathrm{~h}^{-1}$, respectively (Fig. 3a, b). In experiments B and $\mathrm{C}$ (both in mixed waters) and in experiment $\mathrm{E}$ (Atlantic waters), BGR showed higher values for $\mathrm{C}$ additions with values of $3.1,9.1$ and 3.4 day $^{-1}$, respectively (Fig. 3c). Experiments I, H and D (Atlantic, Front and Arctic waters, respectively) presented higher BGR only for $\mathrm{N}+\mathrm{P}+\mathrm{C}$ additions with values of 15.1, 4.3 and $5.8 \mathrm{~d}^{-1}$, respectively (Fig. 3c). Only in experiments I and $\mathrm{H}$, control treatments were similar than in situ BGE (estimated at $10 \mathrm{~m}$ depth, Fig. 3d). Other controls BGE values were higher than the in situ estimations. Values higher than 0.2 were estimated in all the nutrients additions: $\mathrm{N}+\mathrm{P}, \mathrm{C}$ and $\mathrm{N}+\mathrm{P}+\mathrm{C}$, with average values of $0.51 \pm 0.17,0.80 \pm 0.10$ and $0.88 \pm 0.07$, respectively (Fig. 3d).

Bacterial respiration (oxygen consumption in the $<1 \mu \mathrm{m}$ fraction) showed a lower increase in response to enhanced nutrient inputs than BP. Hence, the rate of increase in BP was faster than the oxygen utilisation rate. The changes in bacterial production and respiration were strongly correlated, with oxygen consumption accounting for approx. $50 \%$ of the differences in BP among the experiments $\left(R^{2}=0.46, P<0.001\right)$. The relationship (Fig. 4) between bacterial respiration $\left(\mathrm{BR}, \mu \mathrm{mol} \mathrm{O}_{2} \mathrm{~L}^{-1}\right.$ day $^{-1}$ ) and bacterial production (BP, $\mu$ mol leu $\mathrm{L}^{-1}$ day $^{-1}$ ) was best described by the power equation $\mathrm{BP}=0.125 \mathrm{BR}^{1.30} \pm 0.25$

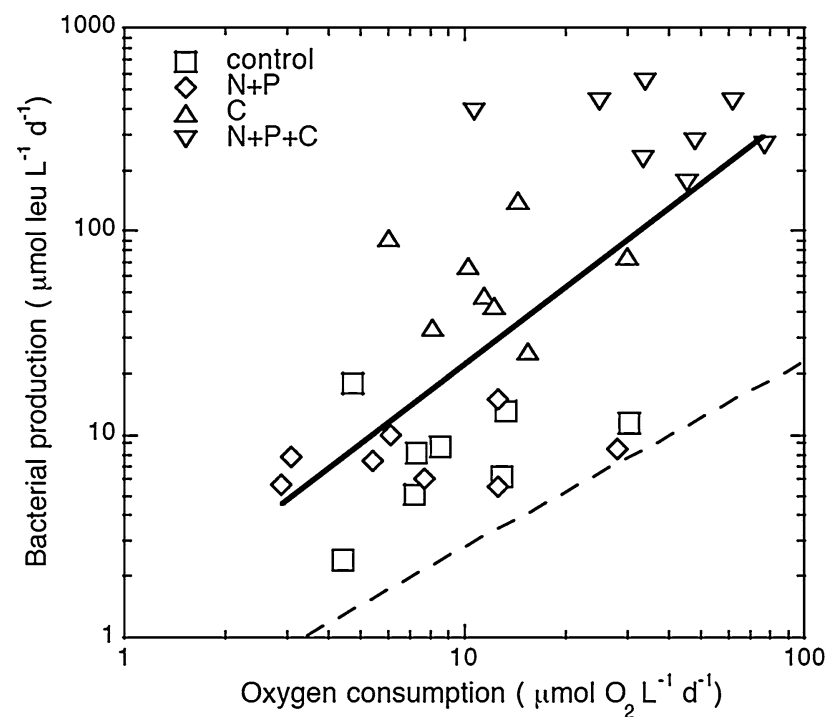

Fig. 4 Relationship between oxygen consumption and bacterial production. The solid line corresponds to the fitted potential equation $\left(\mathrm{BP}=0.125 \mathrm{BR}^{1.30 \pm 0.25}, R^{2}=0.46, n=30, P<0.001\right)$. The dotted line assumes a leucine incorporation factor of $1.5 \mathrm{~kg} \mathrm{C} \mathrm{mol}^{-1}$ (Simon and Azam 1989) and a BGE value of 0.20 (in situ conditions) which indicates that the BP increases as the $\sim 4 / 3$ power of the increase in oxygen consumption.

We considered that carbon or mineral nutrients were limiting when more than one parameter (e.g. oxygen consumption, BP, BGR and BGE) was significant different after its addition. Different levels of significance were used to define possible source limitation by applying a one-way analysis of variance (ANOVA) test over all treatments. ANOVA analysis indicated that during the sampling period, we had a clear carbon limitation since BP for both $\mathrm{N}+\mathrm{P}+\mathrm{C}$ and $\mathrm{C}$ treatment were significantly higher $(P<0.001)$. Less significantly, BGR $(P<0.01)$ and BGE $(P<0.05)$ also showed carbon limitation. Oxygen consumption showed significant differences $(P<0.01)$ only for the $\mathrm{N}+\mathrm{P}+\mathrm{C}$ additions. The $\mathrm{C}$ treatment showed no significant differences, suggesting a possible mineral nutrient co-limitation of oxygen consumption.

Bacterial nuclei acid content and community structure

$\mathrm{N}+\mathrm{P}+\mathrm{C}$ addition gave a huge increase in biomass in all experiments (Fig. 3a). The abundance of LNA bacteria was similar between treatments $\left(\sim 1 \times 10^{6}\right.$ cells $\left.\mathrm{ml}^{-1}\right)$ while HNA bacterial numbers increased with carbon and mineral nutrient addition (data not shown). In the $\mathrm{C}$ and $\mathrm{N}+\mathrm{P}+\mathrm{C}$ treatments, HNA bacteria were 1 and 2 orders of magnitude higher in abundance, respectively, at the end of the incubation period. For all experiments, HNA bacteria were represented by only one group of bacteria in $\mathrm{C}$ and $\mathrm{N}+\mathrm{P}+\mathrm{C}$ treatments (see discussion below). In the $\mathrm{C}$ treatment, HNA bacteria represented on average $55.5 \pm 23.3 \%$ of $\mathrm{BA}$, while in $\mathrm{N}+\mathrm{P}+\mathrm{C}$ treatments, they represented $85.6 \pm 12.6 \%$ of the BA (Fig. 5).

Bacterial community structure revealed by DGGE analysis changed over the incubation time, although not as a response to the carbon or mineral nutrient amendment. NMDS analysis showed two separate bacterial communities, one group consisting of all $T_{\mathrm{f}}$ samples and the other consisting of $T_{0}$ samples (Fig. 6), with a similarity of $>40 \%$ within each group. The DGGE banding patterns were characterised both by disappearance and appearance of bands over time. Using all the sampling sites, $T_{\mathrm{f}}$ samples (13.4 \pm 2.5 DGGE bands) showed a more diverse band pattern compared to the $T_{0}$ samples $(9.6 \pm 2.4$ DGGE bands) with significant differences between $T_{0}$ and $T_{\mathrm{f}}$ samples $(t$ test $=3.70, P<0.005)$.

\section{Discussion}

The seasonal variability in phytoplankton bloom conditions (Dale et al. 1999) and DOC dynamics (Børsheim and Myklestad 1997; Myklestad and Børsheim 2007) observed 


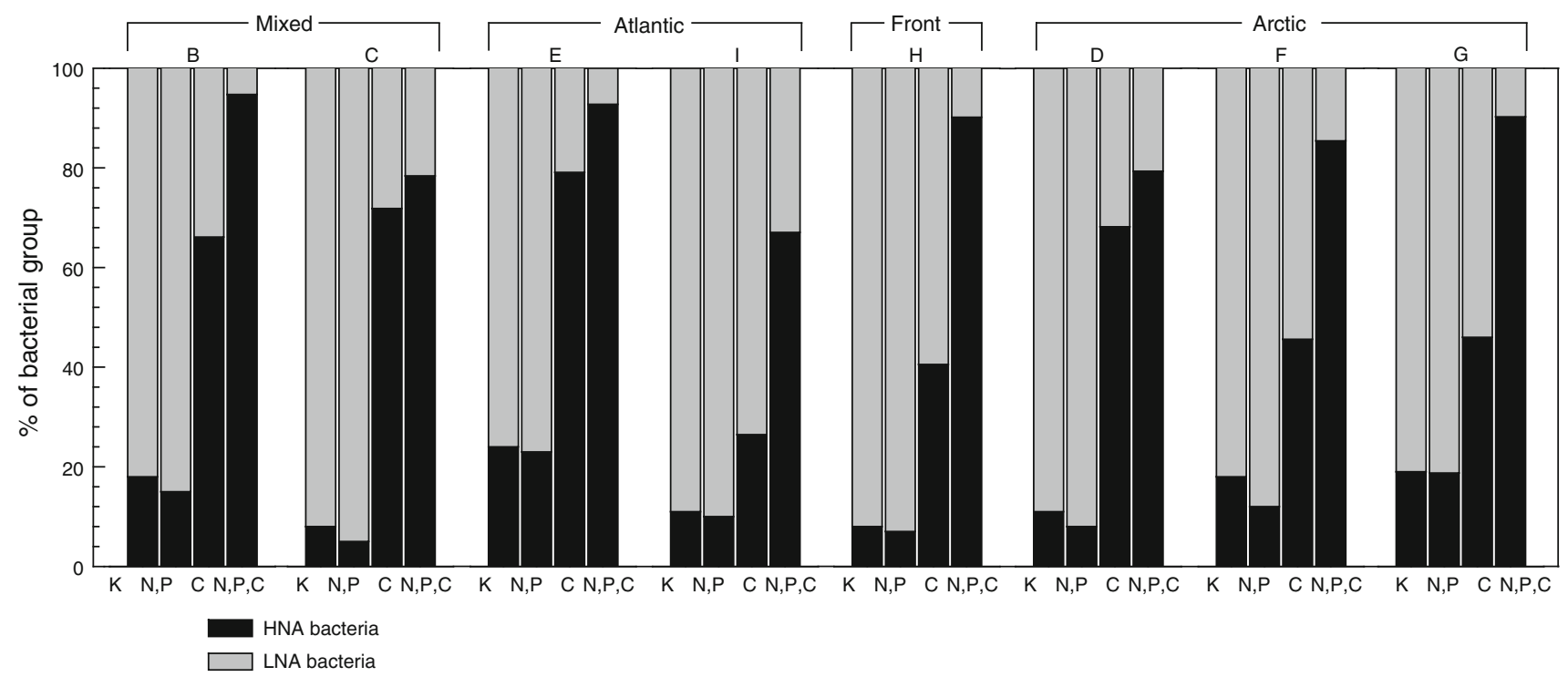

Fig. 5 Percentage of low nucleic acid (LNA) bacteria and high nucleic acid (HNA) bacteria, presented at the end of the incubation period for all the experiments. $\mathrm{K}$ : control; $\mathrm{N}+\mathrm{P}$ : mineral nutrient additions; $\mathrm{C}$ : carbon additions and $\mathrm{N}+\mathrm{P}+\mathrm{C}$ : mineral nutrient plus carbon additions

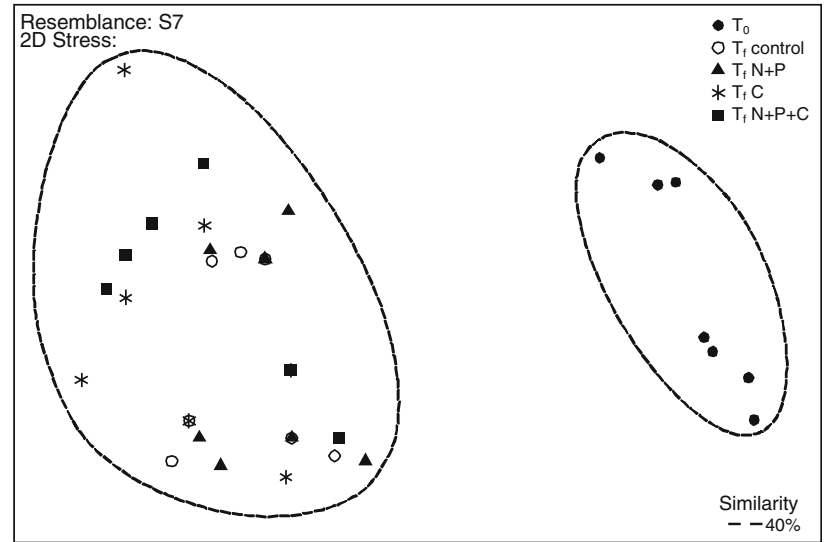

Fig. 6 Non-metric multidimensional scaling (NMDS) plot from the banding pattern of the DGGE analysis. Samples within the dashed circles are $40 \%$ similar in community structure. $T_{0}$ : natural samples at the beginning of each the experiment; $T_{\mathrm{f}}$ samples at the end of the incubation time; $\mathrm{N}+\mathrm{P}$ : mineral nutrient additions; $\mathrm{C}$ : carbon additions and $\mathrm{N}+\mathrm{P}+\mathrm{C}$ : mineral nutrient plus carbon additions

in the Norwegian Sea can potentially provide different states of limitation for bacterial growth characterised by (1) mineral nutrient replete conditions and low concentrations of DOC or (2) mineral nutrient deplete conditions and possible accumulation of organic material. Bacterial growth rate, and thus the fate of labile organic carbon, depends on the type of limitation.

This study took place during May-June 2008 when the Arctic waters supported phytoplankton bloom conditions, while the Atlantic waters were indicative of early bloom conditions (Drinkwater K, pers. comm.). This period was dominated mainly by autotrophic cells between 1-10 $\mu \mathrm{m}$ (nano-phytoplankton, Table 2) with maximum chla values of $2.5 \mu \mathrm{mg} \mathrm{L}^{-1}$ (Tables 1,2) similar to previous studies in the same area (Dale et al. 1999). Surface nutrient concentrations of nitrate, phosphate and silicate were considerable and seemed to be available for phytoplankton and bacteria (Tables 1, 2). Even in experiment $G$ which had rather high chla concentrations $\left(>4 \mu \mathrm{g} \mathrm{L}^{-1}\right)$ and lower nutrient concentration than the rest of the stations, mineral nutrient was probably not limiting for bacteria and nano-phytoplankton (Table 2). TOC concentrations during our experiments $(65.4 \pm 11.2 \mu \mathrm{M}-\mathrm{C})$ were lower than the average DOC values for May-June at station ' $\mathrm{M}$ ' (Børsheim and Myklestad 1997) with values of $86.8 \pm 15.6 \mu \mathrm{M}-\mathrm{C}$. For the same season, Myklestad and Børsheim (2007) suggested that a small fraction of the organic carbon may be available for bacterial utilisation (dissolved carbohydrates represented $14 \%$ and glucose $8 \%$ of the DOC at surface waters). We thereby assume that mineral nutrients were available for phytoplankton and bacteria while less labile organic carbon was released from phytoplankton during early bloom conditions, resulting in a state of bacterial growth limited by labile organic carbon.

Bacterial biomass and activity (oxygen consumption and production) were stimulated significantly by the addition of glucose (Figs. 2, 3) supporting the previous hypothesis and showing that bacterial activity was carbon limited. Previous addition experiments have demonstrated limitation by organic carbon, not inorganic $\mathrm{N}$ and $\mathrm{P}$ in the Arctic (Thingstad et al. 2002; Meon and Amon 2004; Kirchman et al. 2005). A second limiting factor was mineral nutrients (phosphate and ammonia), which in combination with carbon caused a significant increase in bacterial activity and biomass (Fig. 3). Supporting these results, there is 
experimental evidence that the supply of mineral nutrients facilitates the use of semi-labile DOC (Zweifel et al. 1993; Thingstad et al. 1997, 2008). In these cases and similar to our study, mineral nutrient limitation restricts bacterial DOC use, possibly explaining the link between mineral nutrient availability and bacterial activity. For example, $\mathrm{P}$ is an essential nutrient for energy production and biosynthesis, meaning that $\mathrm{P}$ can limit both bacterial respiration and growth. $\mathrm{N}$ in the form of ammonia usually accounts for relatively higher $\mathrm{N}$ uptake rates compared to nitrate uptake in small size cells like bacteria, pico- and nano-phytoplankton (Lipschultz 1995). In the Barents Sea, for example, $53 \%$ of ammonia uptake has been attributed to organisms $<0.8 \mu \mathrm{m}$ (Kristiansen et al. 1994).

BGR was also limited by carbon and mineral nutrients, with significant values for $\mathrm{C}$ treatments $(P<0.01)$, but with variable results between $\mathrm{C}$ and $\mathrm{N}+\mathrm{P}+\mathrm{C}$ treatments (Fig. 3c). BGR can be affected by manipulation of samples, e.g. absence of predators like nanoheterotrophic flagellates and ciliates $(<1 \mu \mathrm{m}$ fraction used during experiments). Furthermore, different approaches to measure growth rate (e.g. changes in bacterial abundance versus incorporation rates) can affect BGR. When bacterial abundance and biomass are determined by direct-count methods, the calculated growth rates can be underestimated because of the presence of nondividing cells. Contrary, when growth rate is calculated from incorporation rates of manipulated experiments (e.g. mineral nutrient additions), higher rates can be calculated. In our study, control $\left(1.05 \pm 0.64 \mathrm{day}^{-1}\right)$ and in situ $\left(0.22 \pm 0.17 \mathrm{day}^{-1}\right) \mathrm{BGR}$ estimations were 2 orders of magnitude higher than in the central Arctic Ocean $\left(0.02 \pm 0.01 \mathrm{day}^{-1}\right)$ in the upper $50 \mathrm{~m}$ (Sherr and Sherr 2003), and also higher than in the western coast of Greenland $\left(0.20 \pm 0.39\right.$ day $\left.^{-1}\right)$ during summer (Møller and Nielsen 2000) and in the western Arctic Ocean (average of $0.13 \mathrm{day}^{-1}$ ) during summer (Kirchman et al. 2009). However, BGR values were in the same range than in the northern Barents Sea $(0.76 \pm 0.91$ $\mathrm{day}^{-1}$ ) during the spring bloom period (Sturluson et al. 2008).

Top-down control (predation and virus lysis) on bacterial growth was not tested in our study. The potential absence of grazers in our experiments (water samples were filtered through $1 \mu \mathrm{m}$ ) can allow higher bacterial biomass and net growth rate compared to unmanipulated experiments. In that sense, other processes such as mineral nutrient competition between osmotrophs (bacteria and phytoplankton) became more important without grazers. Viruses could also affect our incubations, e.g. increasing the production of dissolved organic matter through viral lysis. Lytic viral effect on bacteria will release mostly bioavailable dissolved organic matter (Riemann and Middelboe 2002); thus, the input of carbon and mineral nutrient sources by this process can probably increase bacterial production and growth. An extra artefact that could affect our long incubation time experiments (from 4 to 6 days) is the "bottle effect" in our BGE estimations increasing mainly our bacterial respiration values.

Previous studies have investigated mainly bacterial production in order to determine the factors limiting the utilisation of DOC, while fewer studies have addressed the factors limiting heterotrophic bacterial respiration (Smith and Kemp 2003; Obernosterer et al. 2003, Kirchman et al. 2005, 2009). Total community and bacterial utilisation of oxygen can vary by one order of magnitude in polar areas (Kirchman et al. 2009); hence, the contribution of heterotrophic bacteria to total respiration can also vary. No measurements of total community respiration were carried out during our study, although the $\mathrm{x}$-intercept $(2.5 \mu \mathrm{mol} \mathrm{O}$ $\mathrm{L}^{-1} \mathrm{day}^{-1}$ ) of the relationship between oxygen consumption and bacterial production (Fig. 4) represents the respiration of other microorganisms in the $<1 \mu \mathrm{m}$ fraction that do not incorporate leucine (e.g. cyanobacteria, picophytoplankton). Thus, a high percentage of oxygen consumption $(\sim 87 \%)$ was due to heterotrophic bacteria in the pico-planktonic size fraction. High oxygen consumption rates in experiments with mineral nutrients may seem unrealistic, with maximum values of $28.4 \mu \mathrm{m} \mathrm{O}_{2} \mathrm{~L}^{-1}$ day $^{-1}$ $(\mathrm{N}+\mathrm{P})$ and $76.1 \mu \mathrm{m} \mathrm{O}_{2} \mathrm{~L}^{-1} \mathrm{day}^{-1}(\mathrm{~N}+\mathrm{P}+\mathrm{C})$. However, the slope of the relationship between oxygen consumption and bacterial production (solid line, Fig. 4) was higher than the slope estimated assuming a conversion factor of $1.5 \mathrm{~kg} \mathrm{C} \mathrm{mol}^{-1}$ (Simon and Azam 1989) and an in situ value of 0.20 for BGE (dotted line, Fig. 4). This suggests a high BGE for the bacterial heterotrophic community. In addition, TOC measurements after the incubations in $\mathrm{N}+\mathrm{P}$ treatments seem to have enough carbon to account for the oxygen utilisation estimated during our 4-6 days for experimental incubation (TOC measured values of $78.8 \pm 5.5 \mu \mathrm{M})$. Lack of chemical characterisation is mainly due to the low concentration of individual compounds and the high concentration of inorganic salt that interfere with the chemical measurements (Benner 2002). In that sense, less than $15 \%$ of the total pool of dissolved organic carbon has been characterised (Benner et al. 1992).

The estimated nutrient manipulated BGE values were very high compared to previous values for oceanic areas (del Giorgio and Cole 1998), with variable results possibly due to uncoupling between BP and BR. Higher variability for BP relative to oxygen consumption (Fig. 4), as well as higher variability in BP than BR across different aquatic systems (del Giorgio and Cole 1998), suggests that variations in BGE are mainly regulated by factors that regulate BP. In addition, there is conflicting evidence, and an unclear pattern along trophic gradients, about the role of mineral nutrients in regulating $\mathrm{BGE}$ in natural aquatic 
systems (del Giorgio and Cole 1998). Our BGE calculations also reflect this conflict, showing variable and high BGE in all the bottles amended with mineral nutrients (range of $0.23-0.71$ in $\mathrm{N}+\mathrm{P}$ additions, Fig. 3d). These BGE measurements and their variability may be questioned based on the large uncertainties from a methodological point of view. BP measurements were taken only at the beginning and end of each experiment, while bacterial oxygen consumption was measured every $24 \mathrm{~h}$ for all experiments. Bacterial production tends to vary during long incubation times, with low values at time zero samples, possibly due to filtration effects. It may, however, increase after a few hours of incubation (e.g. after $10 \mathrm{~h}$ ) and decrease or increase at different rates after 2 days (J.M. Gasol, pers. comm.). An extra factor that could affect the high BGE estimations is the possibility that a fraction of the leucine assimilated was transferred to storage compounds and not used in respiration, resulting in an increased BGE.

Uncertainty for our bacterial production estimates was not incorporated into this study, but could potentially affect the higher variability in our BGE estimations (Fig. 3d). For example, the BGE average value of $0.46 \pm 0.16$ for controls was double the values reported previously for other marine areas using short- and long-term incubations (del Giorgio and Cole 1998), and for other estimations of BGE in polar waters $[0.27 \pm 0.01$ in the surface waters of the Arctic's Kara Sea (Meon and Amon 2004) and $0.25 \pm 0.13$ in the Ross Sea (Carlson et al. 1999)]. Only in situ estimations of BGE $(0.20$, Fig. $3 \mathrm{~d})$ were in the same range as previous studies. Hence, we suggest that our absolute BGE values are not so important here, rather than the effect of the treatments.

In the oceanic environment, LNA bacteria are dominant when substrate supply rates are low (Gasol et al. 1995), while the contrary is observed for HNA bacteria when substrates (mineral nutrients and labile carbon) are available. We estimate that 55\% (C treatments) and $85 \%$ $(\mathrm{N}+\mathrm{P}+\mathrm{C}$ treatments) of BA consisted of HNA bacteria when labile substrates were added to our experiments (Fig. 5). This group of HNA bacteria was also present in control and $\mathrm{N}+\mathrm{P}$ treatments with 13 and $11 \%$ of BA, respectively, suggesting that $\mathrm{C}$ and $\mathrm{N}+\mathrm{P}+\mathrm{C}$ amendments were used specifically by HNA bacteria. Although two sub-groups of HNA bacteria were observed in $\mathrm{C}$ and $\mathrm{N}+\mathrm{P}+\mathrm{C}$ treatments, we assume that these two sub-groups represent a single population of heterotrophic bacteria before and after cell division as the size difference between the two was twofold (data not shown).

In contrast to previous studies (e.g. Massana et al. 2001), our observed bacterial community structure was similar at both sides of the sub-polar front, and similar between different substrates added (Fig. 6). It seems that the subpolar front was not an important biological barrier for microbial processes and bacterial community structure using the present detection methods. Bacterial community structure, as determined by DGGE analysis of $16 \mathrm{~S}$ rRNA genes, has an arguably important role on the biogeochemistry of this subarctic area, although our results indicate significant incubation time but not treatment effects. The DGGE profiles analysed here and the metabolic rates estimated may represent the fast-growing populations of bacteria (HNA), but not dominant opportunistic bacteria limited by labile carbon and mineral nutrients.

This subarctic area may maintain both types of bacterial growth limitation depending on the structure of phytoplankton community, mineral nutrient and labile organic carbon concentration. In the case of nano-phytoplankton bloom with mineral nutrients available and bacterial growth limited by carbon, heterotrophic bacteria in the euphotic zone may use all labile organic carbon preventing its accumulation in the euphotic zone. At that point, only phytoplankton production can lead to biological sequestration of atmospheric carbon dioxide. Even though our results cannot be extrapolated beyond the spring bloom period, it is possible that conditions of mineral nutrient limitation of bacteria may arise in other seasons, allowing accumulation of labile DOC and subsequent exportation of carbon to the aphotic zone.

Acknowledgments We thank the captains and the crew of RV Johan Hjort, and K. Drinkwater for organisation during the cruise. We would like to thank also to K.Y. Børsheim who kindly provided the TOC analysis and data and J.L. Ray for language corrections. This work was financed by the International Polar Year project 175939/S30 'PAME-Nor' in cooperation with the Norwegian component of the Ecosystem Studies of Subarctic and Arctic Regions (NESSAR, NFR Project \#-176057). L.A.C. was funded by the EU Marie Curie EST project METAOCEANS (MEST-CT-2005-019678).

Open Access This article is distributed under the terms of the Creative Commons Attribution Noncommercial License which permits any noncommercial use, distribution, and reproduction in any medium, provided the original author(s) and source are credited.

\section{References}

Allen AE, Howard-Jones MH, Booth MG, Frischer ME, Verity PG, Bronk DA, Sanderson MP (2002) Importance of heterotrophic bacteria assimilation of ammonium and nitrate in the Barents Sea during summer. J Mar Syst 38:93-108

Bailey MJ, Lilley AK, Thompson IP, Rainey PB, Ellis RJ (1995) Site directed chromosomal marking of a fluorescent pseudomonad isolated from the phytosphere of sugar beet; stability and potential for marker gene transfer. Mol Ecol 4:755-763

Benner R (2002) Chemical composition and reactivity. In: Hansell D, Carlson C (eds) Biogeochemistry of marine dissolved organic matter. Academic Press, San Diego, pp 59-90 
Benner R, Pakulski JD, McCarthy M, Hedges JI, Hatcher PG (1992) Bulk chemical characteristics of dissolved organic matter in the ocean. Science 255:1561-1564

Børsheim KY (2000) Bacterial production rates and concentrations of organic carbon at the end of the growing season in the Greenland Sea. Aquat Microb Ecol 21:115-123

Børsheim KY, Myklestad SM (1997) Dynamics of DOC in the Norwegian Sea inferred from monthly profiles collected during 3 years at $66^{\circ} \mathrm{N}, 2^{\circ} \mathrm{E}$. Deep-Sea Res II 44(4):593-601

Broström G (1998) A note on the $\mathrm{C} / \mathrm{N}$ and $\mathrm{P} / \mathrm{N}$ ratio of the biological production in the Nordic seas. Tellus 50B:93-109

Carlson CA, Bates NR, Ducklow HW, Hansell DA (1999) Estimation of bacterial respiration and growth efficiency in the Ross Sea, Antarctica. Aquat Microb Ecol 19:229-244

Dale T, Rey F, Heimdal BR (1999) Seasonal development of phytoplankton at a high latitude oceanic site. Sarsia 84:419-435

del Giorgio PA, Cole JJ (1998) Bacterial growth efficiency in natural aquatic ecosystems. Annu Rev Ecol Syst 29:503-541

Elifantz H, Dittel A, Cottrell MT, Kirchman DL (2007) Dissolved organic matter assimilation by heterotrophic bacterial groups in the western Arctic Ocean. Aquat Microb Ecol 50:39-49

Gasol JM, del Giorgio PA, Massana R, Duarte CM (1995) Active vs inactive bacteria: size-dependence in a coastal marine plankton community. Mar Ecol Prog Ser 128:91-97

Giovannoni SJ, Britschgi TB, Moyer CL, Field KG (1990) Genetic diversity in Sargasso Sea bacterioplankton. Nature 345:60-63

Gruber N, Keeling CD, Bates NR (2002) Interannual variability in the North Atlantic Ocean carbon sink. Science 298:2374-2378

Kirchman DL, Malmstrom RR, Cottrell MT (2005) Control of bacterial growth by temperature and organic matter in the Western Arctic. Deep-Sea Res II 52:3386-3395

Kirchman DL, Hill V, Cottrell MT, Gradinger R, Malmstrom RR, Parker A (2009) Standing stck, production, and respiration of phytoplankton and heterotrophic bacteria in the western Arctic Ocean. Deep-Sea Res II 56:1237-1248

Kristiansen S, Farbrot T, Wheeler PA (1994) Nitrogen cycling in the Barents Sea-seasonal dynamics of new ad regenerated production in the marginal ice zone. Limnol Oceanogr 39:1630-1642

Lane DJ, Pace B, Olsen GJ, Stahl DA, Sogin ML, Pace NR (1985) Rapid-determination of $16 \mathrm{~S}$ ribosomal-RNA sequences for phylogenetic analyses. Proc Natl Acad Sci USA 82:6955-6959

Lee S, Fuhrman JA (1987) Relationship between biovolume and biomass of naturally derived marine bacterioplankton. Appl Environ Microb 53:1298-1303

Lipschultz F (1995) Nitrogen-specific uptake rates of marine phytoplankton isolates from natural populations of particles by flow cytometry. Mar Ecol Prog Ser 123:245-258

Malmstrom RR, Straza TRA, Cottrell MT, Kirchman DL (2007) Diversity, abundance, and biomass production of bacterial groups in the western Arctic Ocean. Aquat Microb Ecol 47:45-55

Marie D, Brussaard CPD, Thyrhaug R, Bratbak G, Vaulot D (1999) Enumeration of marine viruses in culture and natural samples by flow cytometry. Appl Environ Microb 65:45-52

Massana R, Pedrós-Alió C, Casamayor E, Gasol JM (2001) Changes in marine bacterioplankton phylogenetic composition during incubations designed to measure biogeochemically significant parameters. Limnol Oceanogr 46:1181-1188

Meon B, Amon RMW (2004) Heterotrophic bacterial activity and fluxes of dissolved free amino acids and glucose in the Arctic rivers Obs, Yenisei and adjacent Kara Sea. Aquat Microb Ecol 37:121-135

Møller EF, Nielsen TG (2000) Plankton community structure and carbon cycling off the western coast of Greenland, with emphasis on sources of DOM for the bacterial community. Aquat Microb Ecol 22:13-25
Muyzer G, Dewaal EC, Uitterlinden AG (1993) Profiling of complex microbial-populations by denaturing gradient gel-electrophoresis analysis of polymerase chain reaction-amplified genes-coding for 16S ribosomal-RNA. Appl Environ Microbiol 59:695-700

Myklestad SM, Børsheim KY (2007) Dynamics of carbohydrates in the Norwegian Sea inferred from monthly profiles collected during 3 years at $66^{\circ} \mathrm{N}, 2^{\circ} \mathrm{E}$. Mar Chem 107:475-485

Obernosterer I, Kawasaki N, Benner R (2003) P-limitation of respiration in the Sargasso Sea and uncoupling of bacteria from P-regeneration in size-fractionation experiments. Aquat Microb Ecol 32:229-237

Øvreås L, Forney L, Daae FL, Torsvik V (1997) Distribution of bacterioplankton in meromictic Lake Saelenvannet, as determined by denaturing gradient gel electrophoresis of PCRamplified gene fragments coding for 16S rRNA. Appl Environ Microbiol 63:3367-3373

Parsons TR, Maita Y, Lalli CM (1984) A manual of chemical and biological methods for seawater analysis. Pergamon Press, New York, pp 173

Pomeroy LR, Wiebe WJ (2001) Temperature and substrates an interactive limiting factors for marine heterotrophic bacteria. Aquat Microb Ecol 23:187-204

Rahmstorf S (2002) Ocean circulation and climate during the past 120, 000 years. Nature 419:207-214

Rich J, Gosselin M, Sherr E, Sherr B, Kirchman DL (1997) High bacterial production, uptake and concentrations of dissolved organic matter in the Central Arctic Ocean. Deep-Sea Res II 44(8): 1645-1663

Riemann L, Middelboe M (2002) Viral lysis of marine bacterioplankton: Implications for organic matter cycling and bacterial clonal composition. Ophelia 56:57-68

Sharp JH, Benner R, Bennett L, Carlson CA, Dow R, Fitzwater SE (1993) Re-evaluation of high temperature combustion and chemical oxidation measurements of dissolved organic carbon in seawater. Limnol Oceanogr 38:1774-1782

Sherr B, Sherr E (2003) Community respiration/production and bacterial activity in the upper water column of the central Arctic Ocean. Deep-Sea Res I 50:529-542

Simon M, Azam F (1989) Protein content and protein synthesis rates of planktonic marine bacteria. Mar Ecol Prog Ser 51:201-213

Smith D, Azam F (1992) A simple, economical method for measuring bacterial protein synthesis in seawater using ${ }^{3} \mathrm{H}$-leucine. Mar Microb Food Webs 6:107-114

Smith EM, Kemp WM (2003) Planktonic and bacterial respiration along an estuary gradient: responses to carbon and nutrient enrichment. Aquat Microb Ecol 30:251-261

Smith WO, Codispoti LA, Nelson DM, Manley T, Buskey EJ, Niebauer HJ, Cota GF (1991) Importance of Phaeocystis blooms in the high-latitude ocean carbon cycle. Nature 352:514-516

Sturluson M, Nielsen TG, Wassmann P (2008) Bacteria abundance, biomass and production during spring blooms in the northern Barents Sea. Deep-Sea Res II 55:2186-2198

Suzuki Y, Tanoue E, Ito H (1992) A high temperature catalytic method for the determination of dissolved organic carbon in sea water: analysis improvements. Deep-Sea Res 19:185-198

Tammert H, Olli K, Sturluson M, Holdal H (2008) Bacterial biomass and activity in the marginal ice zone of the northern Barents Sea. Deep-Sea Res II 55:2199-2209

Teira E, Martínez-García S, Calvo-Díaz A, Morán XAG (2010) Effects of inorganic and organic carbon nutrient inputs on bacterioplankton community composition along a latitudinal transect in the Atlantic Ocean. Aquat Microb Ecol 60:299-313

Thingstad TF, Billen G (1994) Microbial-degradation of phaeocystis material in the water column. J Mar Syst 5(1):55-65

Thingstad TF, Hagström ^, Rassoulzadegan F (1997) Accumulation of degradable DOC in surface waters: Is it caused by a 
malfunctioning microbial loop? Limnol Oceanogr 42(2): 398-404

Thingstad TF, Nielsen TG, Hansen AS, Levinsen H (2002) Control of bacterial production in cold waters. A theoretical analysis of mechanisms relating bacterial production and zooplankton biomass in Disko Bay, Wetern Greenland. Mar Ecol Prog Ser 228:15-24

Thingstad FT, Bellerby RGJ, Bratbak G, Børsheim KY, Egge JK, Heldal M, Larsen A, Neill C, Nejstgaard J, Norland S, Sandaa R-A, Skjoldal E, Tanaka T, Thyrhaug R, Töpper B (2008)
Counterintuitive carbon-to-nutrient coupling in an Arctic pelagic ecosystem. Nature 455:387-390

Töpper B, Larsen A, Thingstad TF, Thyrhaug R, Sandaa R-A (2010) Bacterial community composition in an Arctic phytoplankton mesocosm bloom: the impact of silicate and glucose. Polar Biol doi:10.1007/s00300-010-0846-4

Zweifel U, Norrman B, Hagström Å (1993) Consumption of dissolved organic carbon by marine bacteria and demand for inorganic nutrients. Mar Ecol Prog Ser 101:23-32 